УДК 575.113: 616-006.36:613.63

(C) О. В. Кочетова ${ }^{1}$,

М. К. Гайнуллина ${ }^{2}$, Т. В. Викторова ${ }^{3}$

${ }^{1}$ Учреждение Российской академии наук Институт биохимии и генетики Уфимского научного центра Российской академии наук ${ }^{2}$ ФГУН УфНИИ медицины труда и экологии человека Роспотребнадзора

${ }^{3}$ Башкирский государственный медицинский университет, кафедра биологии

\section{争 Миома матки - \\ мультифакториальное заболевание, в развитии которого принимают участие как генетические, так и внешнесредовые факторы. В данной работе был проведен анализ полиморфных маркеров генов эксцизионной репарации} ДНК (XRCC1, XPD/ERCC2, XPC) и репарации двуцепочечных разрывов ДНК (XRCC3) у работниц крупного нефтехимического комплекса ОАО «Салаватнефтеоргсинтез». Установлено, что гомозиготный по минорному аллелю генотип и минорный аллель полиморфного локуса Gln939Lys (rs2228001) гена $X P C$ ассоциированы с риском развития миомы матки $(3,9$ (95\% CI 1,08-14,4) для генотипа и 2,3 (95\% CI 1,4-3,7) для аллеля). С помощью программы MDR была определена двухлокусная модель взаимодействия ДНК-локусов, приводящая к развитию миомы матки, вариантом повышенного риска является комбинация гетерозиготных генотипов генов $X P C$ и $X R C C 1 A C / A G$ $\mathrm{OR}=2,27(95 \%$ CI 1,04-4,92).

\section{क्ष Ключевые слова:}

гены репарации ДНК;

полиморфные маркеры; миома матки; работницы нефтехимии.

Поступила в редакцию 25.04.2011 Принята к публикации 31.10.2011

\section{ПОЛИМОРФНЫЕ ВАРИАНТЫ ГЕНОВ РЕПАРАЦИИ ДНК (ХRCC1, ХRCC3, ХРD, ХРС) И РИСК РАЗВИТИЯ МИОМЫ МАТКИ У РАБОТНИЦ НЕФТЕХИМИЧЕСКОГО КОМПЛЕКСА}

Миома матки относится к мультифакториальным заболеваниям, которые развиваются в результате комплексного действия генов, ответственных за метаболизм ксенобиотиков, гормонов, факторов роста, цитокинов и генов репарации ДНК, поскольку известно, что миома опосредована воздействием неблагоприятных факторов окружающей среды на организм (Ищенко А. И., 2010). В этой связи очевидно, что на репродуктивное здоровье женщины, являющейся работницей крупного нефтехимического комплекса, происходит постоянное воздействие множества токсических факторов, приводящее к развитию репродуктивных нарушений, в том числе развитию доброкачественного новообразования - миомы матки.

В настоящее время во всем мире идет активное молекулярно-генетическое исследование миомы матки с использованием различных методов. Одним из направлений является изучение ассоциаций полиморфных локусов генов, вовлеченных в патогенез заболевания. Идентифицирован ряд генов, полиморфизм которых ассоциирован с повышенным риском развития миомы матки. Это гены факторов роста, метаболизма и рецепции женских половых гормонов, гены, отвечающие за поддержание стабильности генома (Kitawaki J. et al., 2001 ). Были изучены гены матриксных металлопротеиназ и хемокинов (Морозова с соавт., 2006), цитохромов СYР1A2, СYР19 и сульфотрансферазы (Барков, 2008), факторов роста, ангиогенеза и ферментов биотрансформации (Егорова. и др., 2007), интегринов (Григорьева, 2003), генов репарации ДНК (Jeon, et al., 2005, Yang, et al., 2010).

В патогенезе и развитии миомы матки основополагающая роль отводится эстрогенам (Ищенко, 2010). Механизм возникновения новообразования заключается в том, что снижение активности ферментов метаболизма эстрогенов может приводить к накоплению высокоактивных промежуточных метаболитов и повреждению внутриклеточных структур, главным образом ДНК. На организм работницы в процессе трудовой деятельности происходит воздействие комплекса производственных химических факторов, в частности для таких, как бензол и стирол установлено, что контакт с этими веществами часто приводит к цитогенетическим изменениям, обнаруживаются аддукты в ДНК клетках крови. Система эксцизионной репарации удаления поврежденных оснований (BER) осуществляет защиту геномной ДНК от повреждений, вызываемых главным образом алкилирующими агентами, а также эндогенными генотоксическими соединениями, включая внутриклеточные радикалы кислорода и другие реакционноспособные метаболиты. При нуклеотидной эксцизионной репарации ДНК (NER) поврежденные азотистые основания вырезаются в составе олигонуклеотидов. При дей ствии бифункциональных алкилирующих агентов ДНК могут образовываться так называемые сшивки, эксцизионная репарация которых приводит к появлению двунитевых разрывов. Репарация таких повреждений ДНК осуществляется с помощью генов репарации двуцепочечных разрывов, например XRCC3.

Известно, что среди работниц нефтехимической промышленности чаще, чем среди женщин, не подвергающихся воздействию производственных токсических факторов, встречаются доброкачественные новообразования, такие как миома матки. При стаже работы более 20 лет опухолевые процессы наблюдались в 4 раза чаще, чем в группе работниц со стажем до 10 лет (26,9 против 6,4%, P < 0,05) (Гайнуллина с соавт., 2009). 
Характеристика обследованных групп работниц ОАО «Салаватнефтеоргсинтез»

\begin{tabular}{|c|c|c|}
\hline Показатель & $\begin{array}{c}\text { Работницы с новообразованиями } \\
(\mathrm{N}=104)\end{array}$ & $\begin{array}{c}\text { 3доровые работницы } \\
(\mathrm{N}=85)\end{array}$ \\
\hline Средний возраст, лет: $(\mathrm{M} \pm \sigma)$ & $41,33 \pm 7,99$ & $40,50 \pm 3.89$ \\
\hline Стаж, лет: & & 19 \\
До 15 & 30 & 66 \\
Свыше 15 & 74 & 55 \\
Профессия & 60 & 18 \\
Лаборант & 27 & 12 \\
Қонтролер & 17 & $56 / 28$ \\
Другие & $64 / 40$ & \\
\hline \multicolumn{2}{|l}{} \\
\hline
\end{tabular}

Усиление процессов пролиферации и непосредственное генотоксическое действие эстрогенов и промышленных ядов является важным патогенетическим звеном в онкогенезе, развитии первичной опухоли, дальнейшей опухолевой прогрессии. Учитывая, что миома является опухолью моноклонального происхождения, и произошедшие изменения в одной клетке служат источником клеточной пролиферации, можно выдвинуть предположение, что гены репарации ДНК в развитии миомы матки играют значительную роль (Jeon, 2005). В группу генов, участвующих в механизмах снижения опухолевого роста, можно отнести гены, кодирующие компоненты системы эксцизионной репарации ДНК и репарации двуцепочечных разрывов ДНК. Важнейшими структурными компонентами системы эксцизионной репарации ДНК являются белки, кодируемые генами $X P D / E R C C 2, X P C$ и $X R C C 1$. Одним из основных генов репарации двуцепочечных разрывов ДНК является XRCC3.

В связи с вышеизложенным целью исследования явился анализ частот генотипов и аллелей генов репарации ДНК (XRCC1, XPD/ERCC2, XRCC3, XPC) у работниц $\mathrm{OAO}$ «Салаватнефтеоргсинтез» с миомой матки, здоровых работниц и женщин контрольной группы.

\section{МАТЕРИАЛ И МЕТОДЫ}

Моделью для проведения исследования был выбран производственный нефтехимический комплекс ОАО «Салаватнефтеоргсинтез». В состав объединения входят 30 заводов и производств, выпускающих более 70 наименований продукции, где трудится более 10 тысяч работников. Из числа работающих на данном предприятии женщины составляют около 3 тысяч человек. В воздухе рабочих мест изученных нефтехимических производств присутствует комплекс вредных высокотоксичных химических веществ органической природы (нитрозодиметил амин, нитрозодиметилгидразин, бензол, изобензофуран-1,3-дион, этилбензол, этенилбензол, метилбензол, этилен и др.). Химический фактор в производствах органического синтеза представлен комплексом вредных ве- ществ 1-4 классов опасности с различным характером действия на организм, некоторые из которых обладают отдаленными эффектами воздействия, в том числе и канцерогенным, по шкале МАИР относящимися к 1 и к $2 \mathrm{~A}$ классу опасности. Для многих соединений характерно несколько видов эффектов, причем почти во всех производствах воздействие носит комплексный, комбинированный и интермиттирующий характер. Характеристика обследованных групп работниц показана в таблице 1.

Группы работниц с новообразованиями и здоровые работницы были сопоставимы по возрасту, стажу работы во вредных условиях труда, профессии и этнической принадлежности (табл. 1). Женщины с миомой матки в $71,6 \%$ случаев были представлены работницами, имеющими стаж работы в условиях вредных производств 15 лет и более, среди здоровых на долю работниц со стажем 15 лет и более приходилось $77,8 \%$ человек.

Контрольная группа была представлена здоровыми жительницами Республики Башкортостан, принадлежащими к двум этническим группам - русских и татар, не подвергающимся воздействию производственных химических факторов. Средний возраст женщин контрольной группы составил $41,8 \pm 6,3$ лет.

Материалом для исследования служила геномная ДНК, выделенная из лейкоцитов периферической крови с последующей фенольно-хлороформной экстракцией и осаждением этанолом. Обследованные индивиды прогенотипированы по 4 полиморфным маркерам генов ферментов репарации ДНК ХRCC3 (1045 C>T (Thr241Met) rs861539), XPD (12251A>C (Lys751Gln) rs13181), XRCC1 (1196G>A (Arg399Gln) rs25487), XPC (2919 $C>A$ (Gln939Lys) rs2228001). Для типирования генетических маркеров использован рестрикционный анализ продуктов полимеразной цепной реакции (ПЦР) по методикам, описанным в литературе (Sanyal, et al., 2004; Tuimala, et al., 2002).

Статистическую обработку результатов проводили с использованием программы BIOSTAT (Primer of Biostatistics version 4.03) (BIOSTATISTICA, 1998). Чacтоты аллелей, ошибку и доверительный интервал опре- 
Распределение частот аллелей и генотипов полиморфных маркеров генов XRCC1 (rs25487), XRCC3 (rs861539), XPC (rs2228001), XPD (rs13181) у работниц с миомой матки, здоровых работниц и женщин контрольной группы

\begin{tabular}{|c|c|c|c|}
\hline Генотипы и аллели & $\begin{array}{l}\text { Миома (103)n } \\
\% \text { (ДИ 95\%) }\end{array}$ & $\begin{array}{c}\text { Здоровые (85) n } \\
\text { \% (ДИ 95\%) }\end{array}$ & $\begin{array}{c}\text { Контроль (284) n } \\
\text { \% (ДИ 95\%) }\end{array}$ \\
\hline \multicolumn{4}{|c|}{ XRCC1 (rs25487) } \\
\hline$G G$ & $\begin{array}{c}37 \\
35,92(26,70-45,97)\end{array}$ & $\begin{array}{c}34 \\
5,31(29,52-51,20)\end{array}$ & $\begin{array}{c}133 \\
2,96(40,91-52,82)\end{array}$ \\
\hline$A G$ & $48,54(38,58-58,60)$ & $5,42(37,26-59,34)$ & $\begin{array}{c}120 \\
2,93(36,44-48,23)\end{array}$ \\
\hline$A A$ & $\begin{array}{c}16 \\
3,57(9,15-24,00)\end{array}$ & $\frac{10}{3,49(5,79-20,57)}$ & $\begin{array}{c}31 \\
1,85(7,54-15,13)\end{array}$ \\
\hline$G$ & $\frac{124}{3.41(53.6-66.93)}$ & $\begin{array}{c}109 \\
368(56-42-7132)\end{array}$ & $\begin{array}{c}386 \\
96(6395-7178)\end{array}$ \\
\hline$A$ & $341(3307-4684)$ & $\begin{array}{c}61 \\
3588(2663-4595)\end{array}$ & 182 \\
\hline \multicolumn{4}{|c|}{ XRCC3 (rs861539) } \\
\hline$C C$ & $\begin{array}{c}44 \\
4,87(33,02-52,85)\end{array}$ & $\begin{array}{c}32 \\
5,26(27,36-48,82)\end{array}$ & $\begin{array}{c}98 \\
34,51(28,99-40,35)\end{array}$ \\
\hline$C T$ & $\begin{array}{c}47 \\
491(3578-5574)\end{array}$ & $\begin{array}{c}43 \\
542(39-52-6161)\end{array}$ & $\begin{array}{l}136 \\
4789(4195-5387)\end{array}$ \\
\hline$T T$ & $\begin{array}{r}4,91(00,10-30,14) \\
12\end{array}$ & $\begin{array}{c}0,42(39,02-01,01) \\
10\end{array}$ & 50 \\
\hline$T 1$ & $3,16(6,17-19,47)$ & $3,49(5,79-20,57)$ & $17,61(13,36-22,54)$ \\
\hline$C$ & 135 & 107 & 332 \\
\hline & $3,31(58,61-72,00)$ & $3,70(55,21-70,21)$ & $58,45(54,27-62,54)$ \\
\hline$T$ & $\begin{array}{c}71 \\
3,31(28,00-41,39)\end{array}$ & $\begin{array}{c}63 \\
3,70(29,79-44,79)\end{array}$ & $\begin{array}{c}236 \\
41,55(37,46-45,73)\end{array}$ \\
\hline \multicolumn{4}{|c|}{ XPC (rs2228001) } \\
\hline & $\begin{array}{c}45 \\
43,69(33,94-53,82)\end{array}$ & $\begin{array}{c}56 \\
65,88(54,80-75,82)\end{array}$ & $\begin{array}{c}139 \\
48,94(42,99-54,92)\end{array}$ \\
\hline$A C$ & $\begin{array}{c}45 \\
4369(33.94-5382)\end{array}$ & $\frac{26}{3059(2105-4153)}$ & $\begin{array}{c}118 \\
4155(3576-4752)\end{array}$ \\
\hline & $\begin{array}{c}43,09(33,94-53,82) \\
13\end{array}$ & $\begin{array}{c}30,59(21,05-41,53) \\
3\end{array}$ & $\begin{array}{c}41,50(35, / 0-47,52) \\
27\end{array}$ \\
\hline CС & $12,62(6,89-20,62)$ & $3,53(0,73-9,97)$ & $9,51(6,36-13,53)$ \\
\hline$A$ & 135 & 138 & $\begin{array}{r}396 \\
92\end{array}$ \\
\hline & $\begin{array}{c}65,53(58,61-72,00) \\
71\end{array}$ & $\begin{array}{c}81,18(74,48-86,75) \\
32\end{array}$ & $\begin{array}{c}69,72(65,76-73,47) \\
172\end{array}$ \\
\hline$C$ & $34,47(28,00-41,39)$ & $18,82(13,25-25,52)$ & $30,28(26,53-34,24)$ \\
\hline \multicolumn{4}{|c|}{$X P D($ rs13181) } \\
\hline$T T$ & $\begin{array}{c}41 \\
39,81(30,29-49,92)\end{array}$ & $\begin{array}{c}48 \\
56,47(45,28-67,20)\end{array}$ & $\begin{array}{c}143 \\
50,35(44.38-56,31)\end{array}$ \\
\hline$G T$ & 51 & 28 & 108 \\
\hline UI & $49,51(39,51-59,54)$ & $32,94(23,13-43,98)$ & $38,03(32,36-43,95)$ \\
\hline$G G$ & $\begin{array}{c}11 \\
10,68(5,45-18,31)\end{array}$ & $\begin{array}{c}9 \\
10,59(4,96-19,15)\end{array}$ & $\begin{array}{c}33 \\
11,62(8,13-15,93)\end{array}$ \\
\hline$T$ & 133 & 124 & 394 \\
\hline & $64,56(57,62-71,08)$ & $72,94(65,61-79,46)$ & $69,37(65,39-73,14)$ \\
\hline$G$ & $\begin{array}{c}73 \\
35,44(28,92-42,38)\end{array}$ & $\begin{array}{c}46 \\
27.06(20.54-34.39)\end{array}$ & $\begin{array}{c}174 \\
30,63(26,86-34,61)\end{array}$ \\
\hline
\end{tabular}

деляли методом Клоппера-Пирсона с помощью программного обеспечения Microsoft Excel.

Частоты аллелей и генотипов изученных локусов, соответствие распределения частот генотипов равновесию Харди-Вайнберга $\left(\chi^{2}\right)$ определяли по стандартным фор- мулам при помощи программы электронного калькулятора (http://www.genes.org.uk/software/hardy-weinberg. html), находящегося в свободном доступе.

Ассоциацию с развитием репродуктивной патологии выявляли, сравнивая выборки больных и здоровых 
женщин по частоте одного признака с использованием критерия $\chi^{2}$. Относительный риск заболевания по конкретному признаку вычисляли как соотношение шансов $(\mathrm{OR}-$ odds ratio $) . \mathrm{OR}=(\mathrm{a} \times \mathrm{d}) /(\mathrm{b} \times \mathrm{c})$, где a - частота аллеля (генотипа) в выборке больных, b - частота аллеля (генотипа) в контрольной выборке, с - сумма частот остальных аллелей (генотипов) в выборке больных, d - сумма частот остальных аллелей (генотипов) в контрольной выборке. Доверительный интервал для отношения шансов рассчитывали по формуле (для уровня значимости 95 \%) ДИ $=\operatorname{Exp}(\operatorname{Ln}(\mathrm{OR}) \pm 1,96 * \sqrt{1 / \mathrm{a}+1 / \mathrm{b}+1 / \mathrm{c}+1 / \mathrm{d}})$, где a, b, c, d соответствующие частоты аллелей/генотипов у здоровых и больных.

Межгенные взаимодействия изучали с помощью биоинформатического метода Multifactor Dimensionality Reduction (MDR, v. 2.0 beta8.4 http://sourceforge.net/ projects/mdr).

\section{РЕЗУЛЬТАТЫ}

Определены особенности полиморфизма генов системы репарации ДНК среди работниц с доброкачественными новообразованиями, здоровых женщин-работниц и контрольной группой здоровых женщин, проживающих на территории Республики Башкортостан.

С целью выявления аллелей и генотипов, ассоциированных с предрасположенностью к развитию новообразований, сравнение проводили между работающими женщинами с миомой матки и здоровыми работницами, для выявления маркеров устойчивости к действию токсического производственного фактора проводили сравнение здоровых работниц с контрольной группой, здоровых женщин, проживающих в Республике Башкортостан, не подвергающихся воздействию производственных факторов.

Отклонения от равновесия Харди-Вайнберга в изученных группах работающих женщин и контроля не наблюдалось.

Анализ распределения частот генотипов и аллелей полиморфных маркеров rs25487 гена XRCC1, rs13181 гена $X P D$, rs861539 гена XRCC3 у женщин-работниц с доброкачественными новообразованиями и здоровыми работницами достоверных различий не выявил (табл. 2).

Анализ полиморфного локуса XPC Gln939Lys (rs2228001) выявил различия в распределении аллелей и генотипов при сравнении группы больных миомой и здоровых работниц $\left(\chi^{2}=10,909, \mathrm{df}=2, \mathrm{p}=0,004\right.$ для генотипов и $\chi^{2}=10,685, \mathrm{df}=1, \mathrm{p}=0,001$ для аллелей $)$. Различия были установлены и при сравнении группы здоровых работниц и контроля $\left(\chi^{2}=8,441, \mathrm{df}=2, \mathrm{p}=0,015\right.$ для генотипов и $\chi^{2}=8,025, \mathrm{df}=1, \mathrm{p}=0,005$ для аллелей $)$. Различия были обусловлены повышением частоты генотипа АA в группе здоровых работниц как при сравнении с больными, так и с контрольной группой. Соответственно генотип АА гомозиготы по мажорному аллелю можно считать про- тективным, тогда как гомозиготный по минорному аллелю генотип CC чаще встречается в группе женщин с миомой матки (OR составил 3,9 95 \% CI 1,08-14,4), гетерозиготный генотип АC в группе больных встречается с частотой $43,69 \%$, а среди здоровых $30,59 \%$, однако статистически значимых различий получено не было $\left(\chi^{2}=2,86, \mathrm{df}=1\right.$, $\mathrm{p}=0,09)$. Вместе с тем показано, что минорный аллель С достоверно чаще встречается среди больных работниц, нежели чем среди здоровых (табл. 2), OR составил 2,3 (95\% CI 1,4-3,7), тогда как мажорный аллель А достоверно чаще наблюдался среди здоровых работниц, чем в контроле, OR составил 0,53 (95 \% CI 0,34-0,83).

Основной задачей, стоящей перед генетикой многофакторной патологии, является выявление маркеров высокого риска развития заболевания на основе анализа комбинаций генотипов, однако при выявлении и описании таких маркеров чувствительности к сложному заболеванию встречаются некоторые ограничения и ошибки, когда дело касается большого числа локусов и численности групп. В этой связи представляется интересным использование метода MDR (multifactor dimensionality reduction) в оценке межгенных взаимодействий. Метод MDR был разработан и используется с целью изучения характера межгенных взаимодействий в ассоциативных исследованиях, построенных по принципу случай-контроль в генетике многофакторных заболеваний, использующих относительно небольшие выборки больных и здоровых (Ritchie, 2001 ). Программа позволяет оценить и статистические параметры моделей (точность классификации (accuracy), чувствительность, специфичность, точность модели (precision), отношение шансов (odds ratio)). Метод MDR позволяет представить графически иеархическую структуру и характер взаимодействия между различными генами в виде дендрограммы. При поиске генетических маркеров повышенного риска заболевания нами использовался алгоритм всестороннего поиска (Exhaustive search algorithm), оценивающего все возможные комбинации генетических маркеров.

C помощью программы MDR была определена двухлокусная модель взаимодействия ДНК-локусов, приводящая к развитию миомы матки: генов XRCC1 (Arg399Gln) и XPC (Gln939Lys) с воспроизводимостью 70 \% (CrossValidation Consistency). Тестируемая сбалансированная точность (Bal. Acс.) данной модели составила 0,6139, чувствительность $(\mathrm{Se})-0,64$, повторяемость результата (CV Consistency) - 7/10, p $<0,01$. К сочетаниям повышенного риска развития заболевания были отнесены 6 комбинаций генотипов, наиболее значимая из них XPC $\mathrm{AC} / \mathrm{XRCC} 1 \mathrm{AG}$ OR $=2,27$ (95\% CI 1,04-4,92). На рисунке 1 (a) представлено распределение комбинаций полиморфных локусов генов XPC и XRCC1.

Установлена статистически значимая трехлокусная модель взаимодействия генов XRCC1 (Arg399Gln), XPD (Lys751Gln), XPC (Gln939Lys). Тестируемая сбалансированная точность (Bal. Acc.) данной модели составила 0,52, чувствительность $(\mathrm{Se})-0,3$, повторяемость ре- 
a

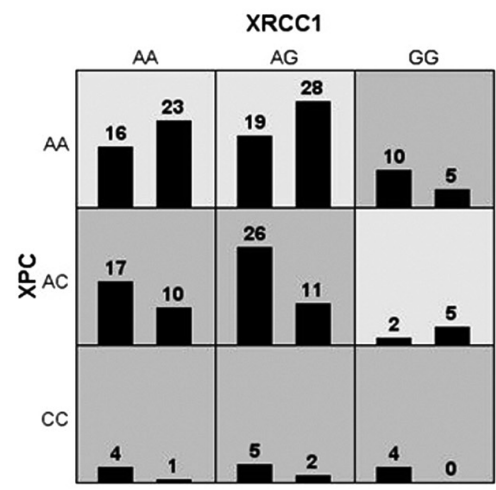

б
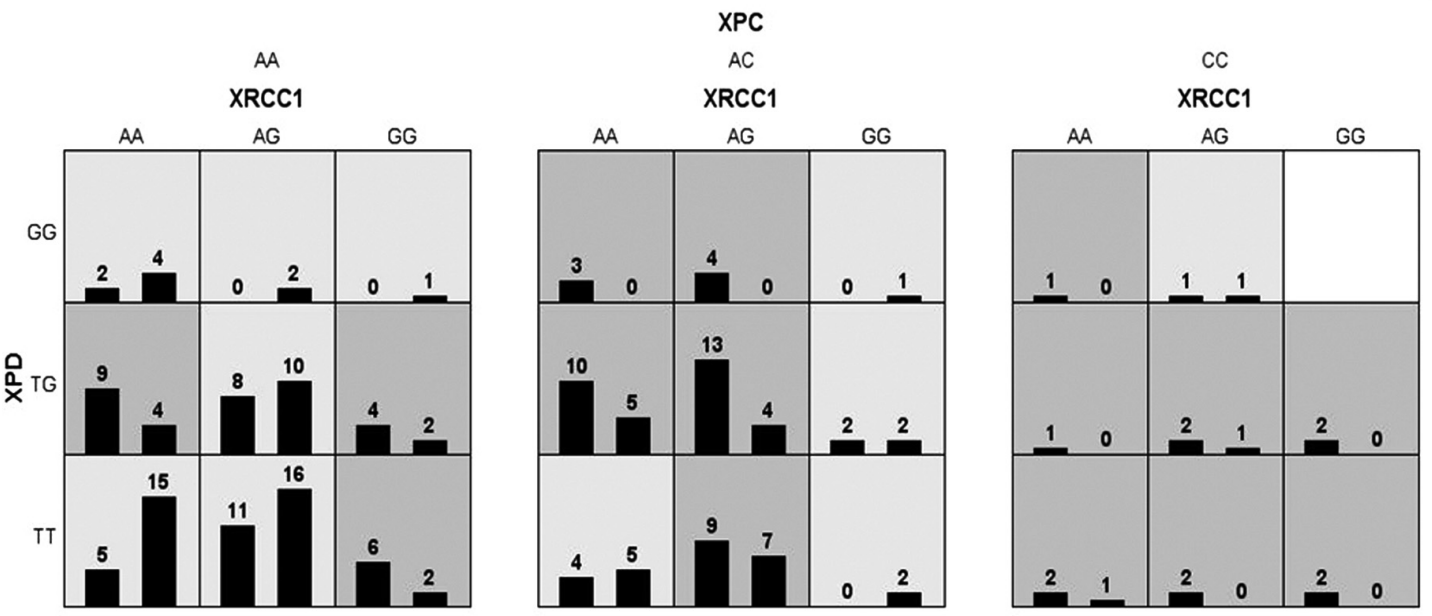

Рис. 1. Распределение частот двухлокусного и трехлокусного сочетаний генотипов генов XRCC1, XRCC3, XPC и XPD у работниц с миомой матки и здоровых:

а Гистограмма сочетаний генотипов генов XRCC1 и XPC;

б Гистограмма сочетаний генотипов генов XRCC1, XPC и XPD.

Темно-серые ячейки — генотипы повышенного риска, светло-серые ячейки-генотипы пониженного риска, белые ячейки отсутствуют сочетания генотипов (левые столбики в ячейках — больные, правые - здоровые индивиды)

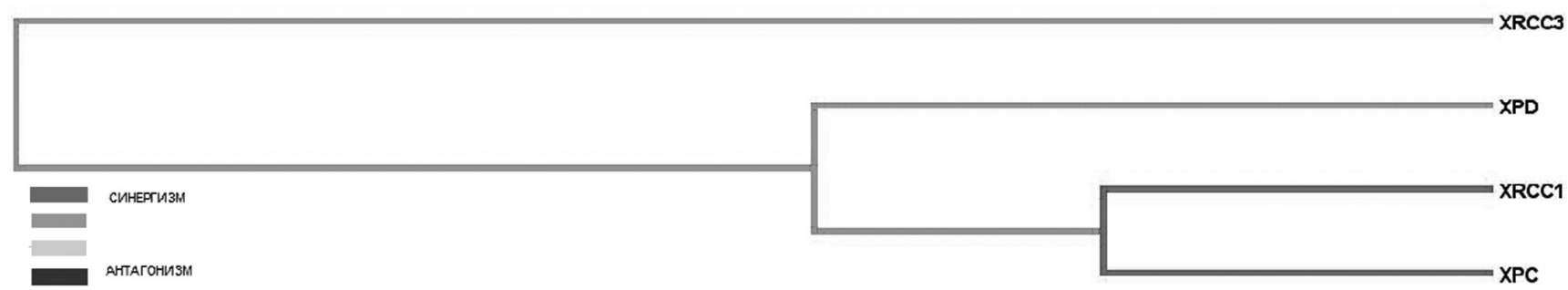

Рис. 2. Дендрограмма межгенных взаимодействий генов XRCC1, XRCC3, XPC и XPD у работниц с миомой матки

зультата (CV Consistency) - 10/10. Однако среди выявленных комбинаций не было обнаружено статистически значимых ассоциаций с риском развития миомы матки (рис 1). Қак следует из гистограммы, наибольшее различие было установлено для комбинации гетерозигот- ных генотипов $T G$ гена $X P D, A G$ гена $X R C C 1, A C$ гена $X P C$ $(13 / 4)$ и только среди больных встречался вариант $G G$ гена $X P D, A G$ гена $X R C C 1, A C$ гена $X P C$.

На рис. 2 можно видеть кластерную структуру взаимодействующих генов, составляющих модель 
межгенных взаимодействий. Показан выраженный синергизм во взаимодействии двух генов эксцизионной репарации XRCC1 и XPC в формировании миомы матки у работниц.

Метод MDR позволяет оценить вклад каждого из исследуемых генотипов, оценить их взаимодействия. Значимость каждого гена и/или их взаимодействия оценивается величиной энтропии и выражается в \%, где $100 \%$ - ситуация, когда знание генотипа однозначно определяет, к какому классу (больных или здоровых) относится индивид, имеющий данный генотип, соответственно, 0 \% - противоположная ситуация, когда генотип не играет никакой роли в предрасположенности к заболеванию. Анализ результатов взаимодействия генов показал, что величина энтропии понижалась от локуса XPC (Gln939Lys) 4,36 \%, XPD (Lys751Gln) 2,23\%, XRCC1 (Arg399Gln) 0,26 \% и XRCC3 (Thr241Met) 0,21\%. Эти результаты согласуются с результатами, полученными при анализе отношения шансов. В нашем исследовании полиморфный маркер Gln939Lys гена XPC выявил наибольшую ассоциацию с риском развития миомы матки у работающих женщин.

\section{ОБСУЖДЕНИЕ}

Исследование функционально значимого генетического полиморфизма важно не только для прогноза возможных генетических или канцерогенных эффектов, но и для определения доли генетической компоненты в общей заболеваемости населения, в частности, мультифакториальной патологией, которая составляет более 50 \% всех нозологических форм. Однако сложность взаимодействий генотип-среда, огромное количество факторов, влияющих на это взаимодействие, осложняет поиск маркеров в любых ассоциативных исследованиях. В этой связи проведение такого рода исследований в группах людей, подвергающихся воздействию вредных химических факторов, зачастую и обуславливающих развитие болезни, представляется наиболее перспективным. Такой подход позволяет выделить лиц наиболее чувствительных к действию определенных токсических веществ, у которых появилось заболевание, и сравнить их с лицами устойчивыми к заболеванию и сохранившими здоровье, несмотря на достаточно большой стаж работы во вредных условиях труда. Сопоставление здоровых лиц, работающих на вредных производствах, с популяционным контролем способствует выявлению генетических маркеров устойчивости индивидов к развитию производст венно-обусловленной патологии. Такие исследования дают возможность установить вовлеченность в патогенез заболевания конкретных генетических маркеров и на основе этого в дальнейшем выявить группы лиц с риском или устойчивостью к развитию эколого-опосредованной патологии.
Значимое место в патогенезе новообразований занимают гены репарации ДНК, которые способны к восстановлению повреждений ДНК, возникающих в результате внешних (канцерогены, ксенобиотики и др.) и внутренних (ошибки репликации) воздействий, и удалению посред ством апоптоза клеток, генетический аппарат которых не может быть восстановлен.

Для примера остановимся на описании генотоксичного воздействия одного из основных токсичных соединений нефтехимического комплекса — бензола. Метаболиты бензола обладают способностью ковалентно присоединяться к таким макромолекулам, как ДНК и белки, что и является причиной возникновения повреждений ДНК или разрывов двойных нитей ДНК. Известно, что устойчивый метаболит бензола р-бензохинон, формирует р-бензохин-С аддукты, являющиеся субстратом для апуриновой/апиримидиновой эндонуклеазы (APE1). После вырезания таких аддуктов в зашивании бреши принимают участие ферменты экцизионной репарации оснований XRCC1, ДНК-лигаза III, в том числе и XPC (Zhang, et al., 2005).

В проведенном исследовании по анализу частоты генотипов и аллелей четырех полиморфных локусов четырех генов репарации ДНК у женщин, работающих в условиях вредных производств, выявлены молекулярногенетические маркеры полиморфного локуса Gln939Lys (rs2228001) гена XPC, ассоциированные с риском развития миомы матки у работниц нефтехимического комплекса и устойчивостью к повреждающему действию производственной среды. Установлено, что гомозиготный по мажорному аллелю генотип можно считать протективным в плане развития миомы матки у женщин производственного комплекса ОАО «Салаватнефтеоргсинтез», тогда как гомозиготный по минорному аллелю генотип ассоциирован с риском развития миомы матки $(\mathrm{OR}=3,995 \%$ CI 1,08-14,4). Минорный аллель $C$ достоверно чаще встречается среди больных работниц, нежели чем среди здоровых (OR $=2,395$ \% CI 1,4$3,7)$, тогда как мажорный аллель А достоверно чаще встречается среди здоровых работниц, чем в контроле $(\mathrm{OR}=0,5395 \%$ CI 0,34-0,83).

XRCC1 является связующим белком, который формирует комплекс эксцизионной репарации оснований (base excision repair, BER) путем индивидуального взаимодействия с каждым компонентом, соединяя ДНКполимеразу $\beta$, ДНК-лигазу IIІа и ПАРП на поврежденном сайте ДНК (Caldecott et al., 1994). Arg399Gln полиморфизм 10 экзона гена XRCC1 затрагивает его центральный домен, необходимый для активации BER. Известно, что аллель $399 \mathrm{Gln}$ характеризуется снижением восстановительной способности и индивиды, имеющие этот аллель, характеризуются повышенной частотой хромосомных разрывов на клетку (Wang et al., 2003) и, соответственно, такие индивиды являются более чувствительными к воздействию химически 
индуцированных генетических повреждений ( Li et al., $2003)$. Носители аллеля 399Gln имеют повышеный риск развития рака простаты, рака легкого, рака печени (Au, 2006; Cornetta, et al., 2006; Aka P., et al., 2004). Jeon с соавторами установлена ассоциация гетерозиготного генотипа Arg399Gln гена XRCC1 с риском развития миомы матки у женщин корейской этнической принадлежности.

Ген XPC играет значимую роль в репарации ДНК путем удаления нуклеотидов (NER - nucleotide excision repair). По данным литературы известна роль полиморфных вариантов этого гена в развитии злокачественных новообразований, так Нu с соавторами выявили ассоциацию гетерозиготного генотипа и гомозиготного генотипа по минорному аллелю локуса Lys939Gln с риском развития рака легкого в Қитае (Hu, et al., 2005). В исследовании Vogel с соавторами также была показана связь минорного аллеля локуса Lys939Gln гена XPC с риском развития рака легкого у европеоидов. Также были выявлены ассоциации вариантов гетерозиготного генотипа и гомозиготного генотипа по минорному аллелю локуса Lys939Gln с раком мочевого пузыря и раком шеи (Qiu, et al., 2008).

Биологическая роль ХРС состоит в том, что этот белок объединяется с HR23B с образованием XPC$\mathrm{HR} 23 \mathrm{~B}$ комплекса, являющегося самым ранним детектором повреждения, который запускает репарацию генома в целом. Комплекс XPC-HR23В после связывания с повреждением индуцирует специфическое конформационное изменение (включая локальное раскрытие ДНК), которое затем инициирует другие факторы, такие как XPA и RPA. По данным литературы известно, что аллель 939C гена ХPC ассоциируется с уменьшением репаративной способности ДНК (Vodicka, et al., 2004).

В нашем исследовании был продемонстрирован выраженый синергизм во взаимодействии двух генов эксцизионной репарации XRCC1 и XPC. При анализе комбинаций генотипов наибольшее число межлокусных взаимодействий зафиксировано для полиморфного локуca Gln939Lys (rs2228001) гена XPC, полиморфизм которого влиял на другие полиморфные локусы в полученных моделях.

Анализ полиморфных вариантов следующего гена эксцизионной репарации XPD/ERCC2 ассоциации с миомой матки не показал. Ген ERCC2 (XPD), так же как и XPC, входит в группу NER-генов. Ген XPD кодирует геликазу, являющуюся частью транскрипционного фактора TFIIH, и, соответственно, изменения, затрагивающие функциональную активность XPD, изменяют способность к восстановлению структуры ДНК, что характеризуется повышением числа ДНК-аддуктов у лиц, носителей этого аллеля (Kiyohara et al., 2007). По данным литературы известно, что аллель $C$ полиморфного маркера Lys751Gln $(A>C)$ ас- социирован со сниженной репаративной способностью гена XPD. Установлено, что аллель $751 C$ обуславливает риск развития аденокарциномы пищевода, рак легкого у европеоидов (Tse et al., 2008; Chang, et al., 2008). Согласно C. Kiyohara (2007) влияние генотипа $G \ln / G \ln$ больше выражено среди популяций Европы $(\mathrm{OR}=2,25,95 \% \mathrm{CI}=0,97-5,23)$ нежели чем Азии $(\mathrm{OR}=1,02,95 \% \mathrm{CI}=0,20-5,27)$, что объясняется имеющимися межэтническими различиями в распределении аллелей и генотипов по данному локусу между населением Европы и Азии и малочисленностью изучаемых выборок.

Ген XRCC3 кодирует белок семейства RecA/Rad51, участвующий в гомологичной рекомбинации, поддер живает хромосомную стабильность путем репарации двухцепочечных разрывов ДНК. Қлетки, не содержащие активный белок XRCC3, имеют дефекты ключево го фермента гомологичной рекомбинации $\operatorname{Rad} 51$, при этом демонстрируется генетическая нестабильность и повышение чувствительности ДНК к повреждающим агентам, что проявляется в повышении уровня ДНК-аддуктов в лимфоцитах у носителей минорного аллеля Т (Matullo, et al., 2001). Наиболее изученный полиморфизм XRCC3 - 18067C4T, (rs861539) транзиция $C$ на Т 7 экзона. В его отношении в литератуpe известны случаи противоречащих ассоциаций. Так в исследовании R. Attar (2010) генотип гомозиготный по мажорному варианту $C C$ гена XRCC3 был установлен как рисковый при формировании эндометриоза у женщин (Attar, et al., 2010). Тогда как по данным T. R. Smith (2003), ассоциация с развитием рака яичников была установлена с минорным аллелем $T$ (Smith, et al., 2003).

Такого рода исследования важны в плане понимания патогенеза миомы матки. Определение генетических маркеров высокого риска развития новообразований у женщин, подвергающихся воздействию вредных химических факторов, позволит разработать рекомендации для выделения женщин в группу риска по развитию репродуктивной патологии (миомы матки).

Работа получила частичную финансовую поддержку Российского фонда фундаментальных исследований 08 04-97007-р_поволжье_а.

\section{Литература}

1. Барков E. С., 2008. Факторы риска в развитии саркомы и миомы тела матки (молекулярно-эпидеми ологический анализ). Автореф. дис. к. м. н. Томск, 2008.

2. Гигани О. О., Буянова Н. И., Соколова С. Л. с соaвm., 2003. Аллельные формы гена бета-цепи интегрина как фактор генетической предрасположеннос- 
ти к некоторым гинекологическим заболеваниям // Вестник Российского университета дружбы народов. Серия: Медицина. № 5. С. 23-28.

3. Егорова О. В., Бермишева М. А., Хуснутдинова Э. К., Глебова Н. Н., 2007. Современные представления о молекулярно-генетических основах миомы матки Медицинская генетика. Т. 6. № 9. C. $11-16$.

4. Ищенко А. И., Ботвин М. А., Ланчинский В. И. 2010. Миома матки. Этиология, патогенез, диагностика, лечение. Видар-М, 244 с.

5. Морозова Е. Б., 2009. Роль генетических и иммунологических факторов в патогенезе лейомиомы матки. Автореф. дис. к. б. н. СПб., 19 с.

6. Гайнуллина М. К., Сивочалова О. В., Бакиров А. Б., 2009. Профессиональный риск нарушений репродуктивного здоровья работниц нефтехимических производств / Под ред М. К. Гайнуллиной - Уфа: ФГУН УфНИИ МТ ӘЧ Роспотребнадзора, Учреждение РАМН НИИ МТ РАМН, $211 \mathrm{c}$.

7. Aka P., Mateuca R., Buchet J. P., Thierens H. et al., 2004. Are genetic polymorphisms in OGG1, XRCC1 and XRCC3 genes predictive for the DNA strand break repair phenotype and genotoxicity in workers exposed to low dose ionizing radiations? // Mutat Res; Vol. 556 P. $169-181$.

8. Attar R., Cacina C., Sozen S., Attar E., Agachan B., 2010. DNA repair genes in endometriosis // Genetics and Molecular Research. Vol. 9. P. 629-636.

9. $A u W . W .2006$. Heritable susceptibility factors for the development of cancer // J. Radiat. Res. Vol. 47B. P. $13-17$.

10.BIOSTATISTICA, Primer of biostatistics version 4.03 by Stanton A. Glanz, McGraw Hill (1998), перевод на русский язык программа BIOSTAT (для IBM PC). «Практика» (1998).

11.Caldecott K. W., McKeown C. K., Tucker J. D. et al., 1994. An interaction between the mammalian DNA repair protein XRCC1 and DNA ligase III. Mol Cell Biol. Vol. 14. N1. P. 68-76.

12. Chang J. S., Wrensch M. R., Hansen H. M., 2008. Nucleotide excision repair genes and risk of lung cancer among San Francisco bay area Latinos and African // Americans Int. J. Cancer. Vol. 123. P. 2095-2104.

13.Cornetta T., Festa F., Testa A., Cozzi R., 2006. DNA damage repair and genetic polymorphisms: assessment of individual sensitivity and repair capacity // Int. J. Radiat. Oncol. Bio.l Phys. Vol. 66. P. 537-545.

14.Hu Z., Wang Y., Wang X. et al., 2005. DNA repair gene XPC genotypes/haplotypes and risk of lung cancer in a Chinese population // Int. J. Cancer. Vol. 115 P. 478-483.

15.Jeon Y-T., Kim J.W., Park N-H. et al., 2005. DNA repair gene XRCC1 Arg399GIn polymorphism is associ- ated with increased risk of uterine leiomyoma // Human Reproduction. Vol. 20., N.6. P. 1586-1589.

16.Kitawaki J., Obayashi H., Ishihara H. et al., 2001. Oestrogen receptor-alpha gene polymorphism is associated with endometriosis, adenomyosis and leiomyomata // Human Reproduction. Vol. 16. N 1. P. $51-55$.

17. Kiyohara C., Yoshimasu K. 2007. Genetic polymorphisms in the nucleotide excision repair pathway and lung cancer risk: A meta-analysis // Int. J. Med. Sci. Vol. 4. N2. P. 59-71.

18. Matullo G., Palli D., Peluso M. et al., 2001. XRCC1, XRCC3, XPD gene polymorphisms, smoking and (32) P-DNA adducts in a sample of healthy subjects // Carcinogenesis. Vol. 22. P. 1437-1445.

19. Qiu L., Wang Z., Shi X., Wang Z. 2008. Genetic polymorphisms in DNA repair genes and possible links with DNA repair rates, chromosomal aberrations and singlestrand breaks in DNA Associations between XPC polymorphisms and risk of cancers: A meta-analysis // Eur. J. Cancer. Vol. 44. P. 2241-2253.

20. Ritchie M. D., Hahn L. W., Roodi N. et al., 2001. Multifactor-Dimensionality Reduction Reveals High-Order Interactions among Estrogen-Metabolism Genes in Sporadic Breast Cancer // Am. J. Hum. Genet. Vol. 69. P. $138-147$.

21.Sanyal S., Festa F., Sakano S. et al., 2004. Polymorphisms in DNA repair and metabolic genes in bladder cancer // Carcinogenesis. Vol. 25. P. 729-734.

22.Smith T. R., Levine E. A., Perrier N. D. et al., 2003. DNA-Repair Genetic Polymorphisms and Breast Cancer Risk // Cancer Epidemiology, Biomarkers \& Prevention Vol. 12. P. 1200-1204.

23.Tse D., Zhai R., Zhou W. et al., 2008. Polymorphisms of the NER pathway genes, ERCC1 and XPD are associated with esophageal adenocarcinoma risk. Cancer Causes Control. Vol. 19. N10. P. 1077-1083.

24.Tuimala J., Szekely G., Cundy S. et al., 2002. Genetic polymorphisms of DNA repair and xenobiotic-metabolizing enzymes: role in mutagen sensitivity // Carcinogenesis. Vol. 23. N 6. P. 1003-1008.

25. Vodicka P., Kumar R., Stetina R. et al., 2004. Genetic polymorphisms in DNA repair genes and possible links with DNA repair rates, chromosomal aberrations and single-strand breaks in DNA// Carcinogenesis. Vol. 25. P. 757-763.

26. Yang Y., Zhai X. D., Gao L. B. et al., 2010. Genetic polymorphisms of DNA repair gene XRCC1 and risk of uterine leiomyoma // Molecular and Cellular Biochemistry. Vol. 338. N 1-2. P. 143-147.

27.Zhang Z., Wan J., Jin X. et al., 2005. Genetic polymorphisms in XRCC1, APE1, ADPRT, XRCC2, and XRCC3 and risk of chronic benzene poisoning in a Chinese occupational population // Cancer. Epidemiol. Biomarkers. Prev. Vol. 14. P. 2614-2619. 


\title{
POLYMORPHISM OF DNA REPAIR GENES (XRCC1, XRCC3, $X P D, X P C)$ AND RISK OF UTERINE MYOMA AMONG WOMEN WORKING IN PETROCHEMICAL COMPLEX
}

\author{
Kochetova O. V., Gainullina M. K., Victorova T. V.
}

SO SUMMARY: Uterine myoma is a multifactorial disease in which the development involving both genetic and environmental factors. In this study we analyzed polymorphisms of genes excision repair (XRCC1, XPD/ER$C C 2, X P C$ ) and repair of double-stranded DNA breaks (XRCC3) among women working at a large petrochemical complex of "Salavatnefteorgsintez". It is established that a minor allele homozygous for the minor allele genotype and polymorphism Gln939Lys (rs2228001) XPC gene are associated with the risk of uterine myoma $(\mathrm{OR}=3.9 \mathrm{CI} 1.001-18.13$ for genotype and $\mathrm{OR}=2.3 \mathrm{CI} 1.36-3.77$ for allele $)$.

KEY WORDS: DNA repair genes; polymorphisms; uterine myoma; petrochemical workers.

Кочетова Ольга Владимировна - к. б. н., научный сотрудник лаборатории физиологической генетики Учреждения Российской академии наук Института биохимии и генетики Уфимского научного центра Российской академии наук. Уфа, 450054, Проспект Октября, 71. E-mail: Olga_makarova78@mail.ru.

Гайнуллина Махмуза Калимовна - д. м. н., руководитель лаборатории «Охрана репродуктивного здоровья работающих» ФГУН УфНИИ Медицины труда и экологии человека Роспотребнадзора. 450006, г. Уфа, ул. С. Кувыкина, 94. E-mail: bakirov@anrb.ru.

Викторова Татьяна Викторовна - д. м. н., заведующий кафедрой биологии. Учреждение Российской академии наук Институт биохимии и генетики Уфимского научного центра Российской академии наук, Уфа, 450054, Проспект Октября, 71. E-mail: tiv@hosp.ru.
Kochetova Olga Vladimirovna - PhD, scientific researcher. Institute of Biochemistry and Genetics. 450054 Ufa, Prospekt Oktyabrya 71. Email: Olga_makarova78@mail.ru.

Gainullina Makhmuza Kalimovna - doctor of medical science, head of the department. Ufa research institute of occupational health and human ecology. Russia, Bashkortostan Republic. 450106, Ufa, St. Kuvikina street,94.E-mail: bakirov@anrb.ru.

Victorova Tatyana Victorovna - doctor of medical science, head of the department.

Institute of Biochemistry and Genetics. 450054 Ufa, Prospekt Oktyabrya 71. E-mail: tiv@hosp.ru 